\title{
ANALISIS PERMASALAHAN MEDIA PEMBELAJARAN DAN PEMBUATAN LKS PADA KURIKULUM 2013 YANG TERJADI PADA GURU KIMIA SMA DI KOTA SAMARINDA
}

\author{
'Maradona, ${ }^{2}$ M.Ikhsan \\ Universitas Mulawarman ${ }^{2}$ Universitas Widyagama Mahakam \\ maradona@fkip.unmul.ac.id \\ ichsan@uwgm.ac.id
}

\begin{abstract}
Abstrak
Analisis permasalahan media pembelajaran dan pembuatan LKS yang terjadi pada guru kimia SMA di kota Samarinda. Metode penelitian secara kualitatif diperoleh melalui observasi, wawancara, dokumentasi dan triangulasi subjek dalam penelitian adalah 3 guru sebagai informan dan 3 responden. Hasil Penelitian menunjukkan bahwa permasalahan yang dihadapi guru kimia dalam membuat Media Pembelajaran kimia dengan pendekatan inkuiri yaitu, keterbatasan teknologi, belum optimal dalam merelevansikan media dengan kondisi kelas. Membutuhkan waktu lama dalam membuat media. Kesulitan dalam memvisualisasikan materi-materi abstark kimia. Permasalahan yang dihadapi guru dalam membuat LKS yaitu, kesulitan dalam membuat soal-soal yang kreatif, kesulitan dalam mengakomodir kontent dengan keadaan lapangan antara mains on dengan hand on, imajinasi, lebih bisa mengkontruksi konsep.

Kata Kunci: Media Pembelajaran, LKS
\end{abstract}

\section{Abstract}

Analysis of the problems of learning media and making worksheets that occur in high school chemistry teachers in Samarinda city. Qualitative research methods obtained through observation, interviews, documentation and triangulation of subjects in the study were 3 teachers as informants and 3 respondents. The results of the research show that the problems faced by the chemistry teacher in making chemical learning media with the inquiry approach, namely, the limitations of technology, have not been optimal in evaluating the media with class conditions. It takes a long time to create media. Difficulties in visualizing chemical abstention materials. The problems faced by the teacher in making LKS are, the difficulty in making creative questions, the difficulty in accommodating content with the state of the field between mains on and hand on, imagination, more able to construct concepts.

Keywords: Learning Media, LKS

\section{PENDAHULUAN}

Ilmu adalah kekuatan yang dapat diperoleh dari intuisi, imajinasi, dan perenungan, juga melalui duduk dibangku sekolah atau kuliah. Pendidikan berperan penting menentukan bagi perkembangan dan perwujudan diri individu, terutama bagi pembangunan bangsa dan Negara. Kemajuan suatu kebudayaan bergantung kepada cara kebudayaan tersebut mengenali, menghargai dan memanfaatkan sumber daya manusia dan hal ini berkaitan erat dengan kualitas pendidikan yang diberikan kepada anggota masyarakatnya kepada peserta didik (Munandar, 1999). Sepanjang sejarah, pendidikan memiliki dua tujuan utama, yaitu membantu orang menjadi pintar dan lebih baik. "Baik" dapat diartikan sebagai nilai-nilai moral yang memiliki kebaikan objektif, yaitu nilai-nilai yang memperkuat martabat manusia dan memajukan kebaikan individu dan masyarakat (Lickona, 2013).

Pendidikan merupakan padanan kata dari pedagogi (Paedagogy). Pedagogi sendiri berasal dari akar kata "paes" yang artinya anak, dan "again" yang dapat diartikan sebagai pembimbing. Dengan demikian pendidikan artinya proses bimbingan yang diberikan kepada anak (Suparlan, 2009). Sebelumnya marilah kita pahami dahulu istilah ilmu pendidikan (paedagogiek) dan ilmu pendidikan (paedagogie). Istilah diatas sebetulnya mempunyai makna yang berlainan "Ilmu Pendidikan mempunyai makna sama dengan istilah "paedagogiek", sedangkan "Pendidikan" sama dengan istilah "Paedagogie". 
Perbedaannya adalah ilmu pendidikan (paedagogiek) lebih menitik beratkan kepada pemikiran permenungan tentang pendidikan. Pemikiran bagaimana sebaiknya sistem pendidikan, tujuan pendidikan materi pendidikan, sarana dan prasarana pendidikan, cara penilaian, cara penerimaan siswa, guru yang bagaimana, jadi di sini lebih menitik

\section{METODE}

Penelitian kualitatif naturalistik memiliki pengaturan yang sebenarnya sebagai sumber langsung dari data dan peneliti adalah sebagai instrumen kunci. Penelitian kualitatif mendeskripsikan data yang diperoleh dari katakata atau gambar daripada angka-angka. Hasil penelitian tertulis mengandung kutipan dari data untuk menggambarkan dan membuktikan presentasi. Penelitian kualitatif konsen dengan proses daripada hasil atau produk, analisis data bersifat induktif dan makna menjadi perhatian penting untuk pendekatan kualitatif (Bogdan dan Biklen, 1998)

Penelitian kualitatif adalah penelitian yang bermaksud untuk memahami fenomena tentang apa yang dialami oleh subjek penelitian misalnya perilaku, persepsi, motivasi, tindakan d1l., secara holistik dan dengan cara deskripsi dalam bentuk kata-kata dan bahasa, pada suatu konteks khusus yang alamiah dan dengan memanfaatkan berbagai metode ilmiah (Moleong, 2006).

Penelitian deskriptif adalah penelitian yang berusaha mendeskripsikan suatu gejala, peristiwa kejadian yang terjadi pada saat sekarang. Dengan kata lain, penelitian deskriptif mengambil masalah atau memusatkan perhatian kepada masalah-masalah aktual sebagaimana adanya pada saat penelitian dilaksanakan (Asmani, 2011).

Deskripsi kualitatif mencakup masalah deskripsi murni tentang program dan / atau pengalaman orang dilingkungan penelitian. Tujuan deskripsi ini adalah untuk membantu pembaca mengetahui apa yang terjadi di

\section{HASIL DAN PEMBAHASAN}

Berdasarkan hasil Observasi, peneliti menemukan media pembelajaran yang digunakan sebatas media umum seperti LCD. LCD berada hanya dikelas tertentu saja. Media beratkan teori. Pendidikan (Paedagogie) lebih menekankan dalam hal praktek, yaitu menyangkut kegiatan belajar- mengajar. Tetapi keduanya ini tidak dapat dipisahkan secara jelas. Keduanya harus dilaksanakan secara berdampingan, saling memperkuat peningkatan mutu dan tujuan pendidikan (Ahmadi dan Uhbiyati, 2003)

lingkungan dibawah pengamatan, seperti apa peristiwa atau aktivitas yang terjadi dilatar penelitian. Desain deskripsi kualitatitif banyak memiliki kesamaan dengan desain deskripsi kuantitatif, karena itu desain deskripsi kualitatif bias disebut pula dengan quasi kualitatif atau desain kualitatif semu (Emzir, 2010)

Peneliti menggunakan metode kualitatif naturalistik, karena permasalahan belum jelas, holistik kompleks, dinamis dan penuh makna sehingga tidak mungkin data pada situasi Sekolah tersebut dijaring dengan metode kuantitatif. Selain itu peneliti bermaksud memahami permasalahan perangkat pembelajaran secara mendalam.

Semua karakteristik dari variabel yang diteliti dalam penelitian ini dideskripsikan sebagaimana adanya tanpa ada perlakuan atau pengendalian secara khusus, juga mempertahankan keutuhan dalam rangka mempelajari tentang obyek dan subyek sebagai suatu keseluruhan yang terintegrasi (Sugiyono, 2011)

Metode penelitian kualitatatif deskriptif adalah suatu metode yang digunakan untuk menemukan pengetahuan terhadap subjek penelitian pada suatu saat tertentu. Kata deskriptif berasal dari bahasa latin “ descriptivus" yang berarti uraian. Penelitian deskriptif merupakan penelitian yang dimaksudkan untuk mengumpulkan informasi mengenai subjek penelitian dan perilaku subjek penelitian pada suatu periode tertentu. Penelitian kualitatif deskriptif berusaha mendeskripsikan seluruh gejala atau keadaan yang ada, yaitu keadaan gejala menurut apa adanya pada saat penelitian dilakukan (Mukhtar, 2013)

yang digunakan, media kondisi seperti Batu Halaman sekolah untuk menghitung bilangan avogadro, dan Motor untuk pembakaran yang tidak sempurna. 
Masalah yang dihadapi guru dalam menyusun media pembelajaran yaitu, keterbatasan Teknologi, belum mampu secara optimal untuk merelevansikan media dengan kondisi kelas. Butuh waktu dalam mempelajari aplikasi-aplikasi baru. Kesulitan dalam memvisualisasikan materi-materi abstrak dengan menggunakan media

\section{$(\mathrm{Ct1} / \mathrm{Ww} / \mathrm{ES} / 35-13-14)$} pada box

Berdasarkan hasil wawancara diatas, maka Critical Incidence tema - tema unik seperti terlihat

Berdasarkan hasil wawancara diambil kesimpulan beberapa kendala yang dihadapi guru kimia kelas XI SMA Negeri kota Samarinda dalam membuat media pembelajaran sebagai berikut:

a. Keterbatasan waktu

b. Kesulitan dalam menggunakan aplikasi-aplikasi baru

c. Kesulitan dalam memvisualisasikan materi-materi abstrak kimia

d. Media umum digunakan seperti power point saja

e. Kesulitan dalam memperhatikan relevansinya dengan kemampuan peserta didik dan kemampuan awal peserta didik.

Media pembelajaran berbasis inkuiri harus dirancang, disusun, dibuat, dan disiapkan sedemikian rupa oleh guru. Oleh karena itulah, media yang diterapkan dalam suatu proses pembelajaran merupakan suatu karya dan digolongkan sebagai "teknologi dalam pembelajaran".

Jenis media yang digunakan seluruh guru meliputi: media berbasis manusia (guru, tentor sebaya dan kegiatan kelompok), media berbasis cetakan (LKPD, Buku paket, modul), media berbasis visual (papan tulis, buku paket, modul,LKPD, gambar, alat-alat peraga), dan media berbasis komputer (Microsoft Office PowerPoint).

Merencanakan penggunaan media pembelajaran berbasis inkuiri harus memperhatikan kebutuhan dan karakter peserta didik, tujuan yang ingin dicapai, perumusan butir-butir materi, permusan alat pengukur keberhasilan, penulisan naskah media, mengadakan tes dan revisi. Sehingga keterbatasan waktu yang dimiliki guru menjadi faktor penghambat terbesar dalam merencanakan penggunaan media pembelajaran salah satu penyebab keterbatasan waktu ini yaitu tuntutan beban jam mengajar dalam setiap minggunya sebanyak 34 jam.

Dari hasil analisis data yang diperoleh dengan triangulasi data, wawancara dan dokumentasi, maka diperoleh keseluruhan guru dalam menyusun media berbasis cetakan yaitu LKPD masih belum mengarah pada model pembelajaran inkuiri. Dikarenakan LKPD yang dirancang oleh seluruh guru didalamnya tidak menggunakan langkah - langkah inkuiri.

Karakteristik LKPD dengan pendekatan inkuiri yaitu adanya suatu alat bantu berupa benda nyata yang dapat membantu peserta didik dalam melakukan kegiatan-kegiatan yang ada didalam LKPD untuk memahami konsep asam-basa adanya pertanyaan yang disebut rumusan masalah di awal setiap kegiatan yang bertujuan memfokuskan konsentrasi peserta didik pada materi yang akan dipelajari. Adanya aktivitas yang harus dilakukan dan pertanyaan-pertanyaan yang dapat membimbing peserta didik untuk melakukan proses penemuan konsep materi yang sedang dipelajari baik melalui pengamatan atau uji coba secara langsung (observasi atau eksperimen). Adanya pertanyaan-pertanyaan yang mengarahkan peserta didik menganalisis hasil penemuannya dari kegiatan observasi atau eksperimen sebelum peserta didik membuat kesimpulan mengenai konsep yang sedang dipelajarinya (analisis temuan). Adanya pertanyaan yang mengarahkan peserta 
didik untuk menyimpulkan konsep yang telah mereka temukan (kesimpulan). Adanya soal pada setiap akhir kegiatan. Digunakan untuk menguji serta memantapkan pemahaman peserta didik terhadap sub materi yang sudah dipelajari.

LKPD yang dihasilkan, terdapat beberapa komponen yaitu bagian awal, bagian inti, dan bagian akhir. Pada bagian awal terdapat halaman sampul, cakupan kompetensi, petunjuk peserta didik, dasar teori, dan indikator. Halaman sampul mewakili keseluruhan isi Lembar Kerja Peserta didik, berisi judul (materi), pengguna (nama, kelas, semester), dan gambar yang relevan dengan materi. Cakupan kompetensi merupakan paparan mengenai $\mathrm{KI}, \mathrm{KD}$, Indikator dan tujuan kegiatan pembelajaran dari materi yang dikembangkan dalam LKPD. Petunjuk peserta didik berisi hal-hal yang harus dilakukan peserta didik sebelum dan saat melakukan kegiatan - kegiatan dalam Lembar Kerja Peserta didik. Tengok Materi berfungsi memberikan gambaran dan menata alur pikir peserta didik tentang garis besar materi yang akan dipelajari. Sedangkan indikator menginformasikan kepada peserta didik tentang kompetensi-kompetensi yang harus dicapai pada tiap kegiatan belajar. Selanjutnya adalah bagian isi. Bagian ini terdiri dari rumusan masalah, observasi, menganalisis temuan, kesimpulan, dan uji pemahaman. Rumusan masalah adalah tahap untuk membawa peserta didik pada suatu persoalan terkait submateri yang dipelajari, dan dirumuskan dalam bentuk pertanyaan yang akan dipecahkan melalui proses inkuiri terbimbing. Observasi adalah tahap dimana peserta didik melakukan pengamatan dan percobaan untuk menjawab pertanyaan yang diberikan. Menganalisis temuan berisi pertanyaanpertanyaan yang membantu peserta didik menganalisis data observasi agar peserta didikmemukan konsep-konsep materi secara berkelompok. Kesimpulan merupakan tahap untuk membimbing peserta didik menyimpulkan konsep yang telah ditemukan pada tahap sebelumnya. Uji pemahaman, digunakan untuk menguji serta memantapkan pemahaman peserta didik terhadap sub materi yang sudah dipelajari.Selanjutnya yaitu bagian penutup. Bagian ini hanya berisi soal-soal evaluasi dari materi hubungan asam impuls.

Dari hasil analisis data yang diperoleh dengan triangulasi data, wawancara dan dokumentasi, keseluruhan guru menyatakan bahwa mereka mengetahui salah satu program didalam komputer yang bisa dijadikan media didalam pembelajaran yaitu Microsoft Office PowerPoint. Pengajaran dengan menggunakan media Power Point dirasa memudahkan para guru untuk menyampaikan materi sehingga pengajaran tidak terasa membosankan dan peserta didik akan lebih terfokus konsentrasinya ketika slide demi slide ditampilkan, suasana di kelas pun lebih kondusif atau terkontrol selama jam pelajaran. Hal ini membuktikan bahwa pengajaran dengan media PowerPoint lebih menarik perhatian peserta didik.

Kualitas media pembelajaran berbasis Microsoft Office PowerPoint yang disusun oleh guru Kimia kelas XI SMA Negeri sekota Samarinda ditinjau dari aspek isi pembelajaran yaitu materi yang disajikan telah sesuai dengan indikator pencapaian kompetensi, namun masih kurang mendetail dalam menyajikan materi.

Permasalahan yang dihadapi guru Kimia kelas XI SMA Negeri sekota Samarinda dalam menyusun media pembelajaran berbasis Microsoft Office Power Point pada materi asam-basa ditinjau dari aspek desain pembelajaran yaitu dua dari tiga guru menyatakan PowerPoint membuat lebih mudah memahami pelajaran dan sisanya lagi menyatakan powerpoint membuat lebih susah memahami pelajaran, disebabkan oleh faktor: materi yang disajikan kurang mendetail, slide yang ditayangkan terlalu cepat pergantiannya, dan slide yang ditayangkan kurang menarik. Permasalahan yang dihadapi guru Kimia kelas XI SMA Negeri sekota Samarinda 
dalam menyusun media pembelajaran berbasiss Microsoft Office PowerPoint pada materi asam-basa ditinjau dari aspek media pembelajaran yaitu penggunaan sound effect yang kurang tepat, gambar-gambar yang tidak berhubungan dengan materi dan terdapat dua guru yang mengetahui dan paham akan fungsi setiap menu dalam Ms. Power Point dan sisanya hanya mengetahui beberapa menu umum yang cenderung sering digunakan. Hal ini disebabkan kurangnya pengetahuan dan keterampilan guru tersebut tentang kemajuan teknologi. Ketidaktahuan terhadap menu-menu tool-bar yang ada didalam Power Point mengakibatkan sulitnya merancang animasi didalam Power Point.

Keseluruhan guru menyatakan tidak selalu menggunakan media Power Point hanya untuk menyampaikan materi, tetapi media tersebut juga digunakan sebagai bahan evaluasi seperti penyajian tes, penyajian game, pemutaran video audio dan lain-lain. Selain penggunaan media Power Point dalam proses pembelajaran, setiap guru mengetahui adanya media lain yang dapat digunakan sebagai media pembelajaran kimia. Contoh media yang dapat digunakan antara lain Ms. Word, Ms. Excel dan lain - lain. Keseluruhan guru mengetahui akan adanya alat pendukung lain yang dapat digunakan dalam penyajian materi, seperti penggunaan infocus, speaker dan perangkat lainnya. Akan tetapi sayangnya, media PowerPoint dalam kurun waktu yang akan datang, keseluruhan guru lebih tertarik dengan media pembelajaran lain dalam penyajian materi, misalnya penggunaan media player. Karena itulah keseluruhan guru menyatakan adanya media pembeljaran yang lebih efektif digunakan selain Microsoft Office PowerPoint dalam penyajian materi, contohnya Media Player.

Berdasarkan hasil Observasi, peneliti menemukan LKS yang memuat materi sedikit LKS, contoh-contoh pengembangan soal kurang.

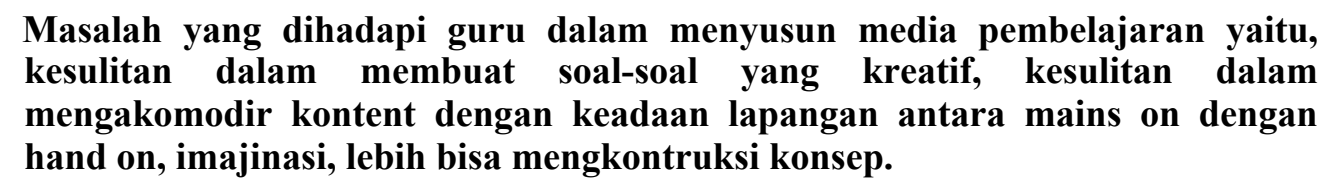

Box Masalah yang dihadapi guru dalam menyusun LKS

Berdasarkan hasil wawancara diambil kesimpulan beberapa kendala yang dihadapi guru kimia kelas XI SMA Negeri kota Samarinda dalam menyusun LKS sebagai berikut:

a. Perlu waktu lama

b. Biasanya LKS yang dibuat, berbeda dengan keadaan bahan-bahan kimia yang tersedia, dilaboratorium. Biasa alaalat di LKS tidak ada di Lab.

c. Perlu membuat soal-soal yang kreatif.

d. Kesulitan dalam mengakomodir kontent dengan keadaan lapangan antara mains on, imajinasi dan lebih bisa mengkontruksi konsep.
Peneliti menemukan permasalahan guru yaitu, waktu untuk membuat LKS cukup lama, guru kekurangan referensi buku-buku pendukung. Guru kesulitan dalam mengakomodir content.

\section{KESIMPULAN}

1. Permasalahan yang dihadapi guru dalam membuat Media Pembelajaran kimia dengan pendekatan inkuiri yaitu, keterbatasan teknologi, belum optimal dalam merelevansikan media dengan kondisi kelas. Membutuhkan waktu lama dalam membuat media. Kesulitan dalam memvisualisasikan materi-materi abstark kimia. 
2. Permasalahan yang dihadapi guru dalam membuat LKS yaitu, kesulitan dalam membuat soal-soal yang kreatif, kesulitan dalam mengakomodir kontent dengan keadaan lapangan antara mains on dengan hand on, imajinasi, lebih bisa mengkontruksi konsep.

\section{DAFTAR PUSTAKA}

Asmani, Jamal M. 2011. Penelitian Pendidikan. Jogjakarta: Diva Press

Emzir. 2010. Metodologi Penelitian Pendidikan.

Jakarta: Rajagrrafindo

2012. Buku Panduan

Internalisasi Pendidikan Karakter

disekolah. Jogjakarta: Diva Press

Lickona, T.. 2013. Educating for Caracter. Jakarta :Bumiaksara, RemajaRosdakarya,

Moelong, L. J..2006. Metodologi Penelitian

Kualitatif. Bandung: Rosda

Mukhtar. Metode Praktis Penelitian Kualitatif.

Jakarta: Referensi

Munandar,U.. 1999. Pengembangan Kreativitas Anak Berbakat. Jakarta: RinekaCipta . 2011. Penilaian Berbasis Kelas

dan Kompetensi. Malang :RefikaAditama

:SinarBaruAlgensindo

Suparlan. 2009. Tanya Jawab Pengembangan Kurikulum dan Materi Pembelajaran. Jakarta: Bumiaksara

Sugiyono. 2005. Memahami Penelitian Kualitatif. Bandung : PT. Tarsito 